\title{
An African Communitarian Response to Robert Nozick's Political Philosophy
}

\author{
Precious Uwaezuoke Obioha, Ph.D \\ Department of Philosophy, Akwa Ibom State University, Obio Akpa Campus, Oruk Anam - Nigeria \\ Emmanuel Jerome Udokang, Ph.D \\ Department of Philosophy, Akwa Ibom State University, Obio Akpa Campus, Oruk Anam - Nigeria
}

\begin{abstract}
Robert Nozick's attempt to contribute to the existing corpus on the best possible way to achieve a good human community conducive for the realization and flowering of human well-being must be seen as a bold step to change the political cum socio-economic landscape of the world environment. This is expected of every political philosopher, to deploy his/her wealth of philosophical arsenal towards changing our world and making it conducive for the achievement of the summum bonnum. However, Nozick's political thoughts have far reaching implications for human well-being and the establishment of a good human community. The paper through the analytical and critical methods of a philosophical research, argues against certain positions which Nozick has taken in his political thoughts. The paper claims that Nozick's thought sparks an extreme form of unbridled individualism and that Nozick's entitlement theory lacks the human feelings of sympathy, co-existence, acceptance, care and concern requisite for building a good human community. The paper finally advocates for a political thought and arrangement that tries to minimize the plights and the sufferings of the disadvantaged and worse off members of the human community made possible through the virtues of sympathy, love, compassion, acceptance, co-existence and care espoused in African Communitarian idea of justice.
\end{abstract}

DOI: $10.7176 / \mathrm{JPCR} / 47-02$

Publication date: December $31^{\text {st }} 2019$

\section{Introduction}

From the distant past to the present time, political philosophers have always asked questions and brainstormed on how best to achieve a good human community for the full realization of man's personhood and the flowering of his potentialities and personality. Perhaps this is why N. Warburton defines political philosophy as philosophical reflection on how best to arrange our society in terms of political and social practices. To do this, it seeks to establish basic principles that will justify a particular form of state, what constitutes individuals' inalienable rights and why they possess them. It also seeks to establish ideas on how to share the society's resources among its members. This makes, therefore, the concepts of freedom, rights, authority, justice etc. recurrent decimals in any political discourse.

The quest for a good human community is certainly the focus of Robert Nozick in his philosophico-political undertaking. The focus of this paper, which is also a philosophico-political discourse, is to seek an understanding of Robert Nozick's political philosophy and to posit a critique to it. Critical remarks made on his political thoughts, guided by African Communitarian idea of justice, will form a template for further discussions.

\section{Robert Nozick's Political Philosophy}

Although Robert Nozick did not consider himself to be primarily a political philosopher, however his contribution to political philosophy is enormous and he is best known for his contributions to it. Dale Murray (2014) puts it succinctly thus, "undoubtedly, Nozick's work in epistemology and metaphysics (especially with respect to free will and the "closest container" theory of personal identity) has had a significant impact on those fields. However, it was the publication of his first book, Anarchy, State and Utopia (1974) that revitalized the political right-wing and set off a firestorm of critical replies and commentaries". Nozick's work attempts to provide a justification for the state; to set the limits of government; and to convince us that accepting his minimal State could foster a framework for building a good human community.

A good understanding of Nozick's political thought, expressed in his quest for the achievement of a good human community, requires an adequate knowledge of the key terms that underlie his thought namely, Individualism, Justice and the Minimal State.

\section{Individualism}

Nozick has a conception of separateness of persons. Using kant as an inspiration, Nozick argues that individuals are ends in themselves. Earlier, Kant has argued that for individuals to be different "ends-in-themselves", people must be separate entities. As distinct individuals, each of us matter from a moral point of view. This implies that benefits to some supposed larger entity, such as the "greater society" cannot be used as a justification for 
violating individuals as persons all in the name of the common good. As regards the idea of the common good, Nozick does not believe that such exists. To him, there are merely individuals and the common good can only really be the good of individuals added together. It further implies that while it is true that some individuals might make sacrifices of some of their interests in order to gain benefits for some other of their interests, society can never be justified in sacrificing the interests of some individuals for the sake of others.

The doctrine of the separateness of persons supports Nozick's existence of moral side-constraints that individuals possess. Moral side-constraints set the boundaries for what can permissibly be done to people (whether by other individuals or the State). Violations of such side constraints are wrongful in that they treat individuals who suffer such violations as means or instruments to the ends of other people. Murray (2014) points out that side constraints as understood by Nozick, are absolute prohibitions on what can permissibly be done to individuals. That is, even if we thought that violation of the moral side-constraints of just one person could be to the benefit of many others within the society such a violation could not be justified.

Self-ownership is therefore the cornerstone of Nozick's political thought. Galvin Chia (2010) amplifies this view of Nozick when he says that, as individuals own themselves, they cannot be treated as means and must be seen as ends, in Kantian fashion. According to G.A. Cohen (1995), self-ownership accords individual's right to be treated as ends and not as means. In the same light, Alan Goldman (1976) points out that Nozick defines rights to be natural rights which are inalienable and inviolable. This conception of right grants moral equality to all individuals.

Stemming from his concept of self-ownership is his entitlement theory which defines how individuals may justly come to possess things. The entitlement theory defines his conception of justice.

\section{Justice}

Nozick's conception of justice is a narrow one grounded in the non-violation of property rights. His conception of justice has three main principles. First is the concept of justice in acquisition. This principle of justice deals with the initial acquisition of holdings. It is an account of how people first come to own common property, what types of things can be held etc. It states that a possession is justly held if it was acquired in a just fashion - that is acquired without the violation of another's self-ownership or right to property. The second is justice in transaction/transfer which explains how one person can acquire holdings from another including voluntary exchange and gifts. It states that whatever is justly held can be freely transferred. Here, the notion of 'free' would mean freedom from force, theft, fraud, and so on (Kymlicka, 2002). If someone who justly owns something freely transfers that property to another, then it is just for that other person to own it - provided that it does not leave others worse off.

The third is the principle of rectification of injustice which stipulates how to deal with holdings that are unjustly acquired or transferred, whether and how much victims can be compensated, how to deal with long past transgressions of injustices done by a government etc. In this principle, if the current distribution of property holdings is the result of unjust acquisitions, then a distribution which would have arisen had the transaction been just must be realized (Nozick, 1974). What this shows is that, historically, unjust acquisition in the past must be rectified.

Nozick (1974) believes that if the world were to be entirely just, only the first two principles would be needed. Inductively the following will exhaustively cover the subject of justice in holdings:

1. A person who acquires a holding in accordance with the principle of justice in acquisition is entitled to that holding.

2. A person who acquires a holding in accordance with the principle of justice in transfer, from someone else entitled to the holding, is entitled to the holding.

3. No one is entitled to a holding except by (repeated) application of 1 and 2. (p.106).

What the above excerpt shows is that entitlement theory would imply, "a distribution is just if everyone is entitled to the holdings they possess under the distribution" (Nozick, 1974. P.106). But according to Nozick (1974), unfortunately, not everyone follows these rules. He says:

Some people steal from others, or defraud them, or enslave them, seizing their product and preventing them from living as they choose, or forcibly exclude others from competing in exchanges. Thus the third principle of rectification is needed (152).

In the entitlement theory, Nozick fails to say anything about the process of initial appropriation. He rather appeals to 'Lockean Provisio' as a basis for his claims. Lockean Provisio bespeaks of Locke's theory of property according to which a person (being a self-owner) owns his labour, and by "mixing his labour" with a previously unowned part of the natural world (e.g. by whittling a stick found in a forest into a spear) thereby comes to own it. This shows that an individual can legitimately claim possession of the natural world. Kymlicka (2002) summarizes it thus:

(i) People own themselves. (ii) The world is initially unowned. (iii) You can acquire absolute rights over a disproportionate share of the world, if you do not worsen the condition of others. (iv) It is relatively easy to 
acquire absolute rights over a disproportionate share of the world.

Therefore, once people have appropriated private property, a free market in capital and labour is morally required (104).

Nozick's entitlement theory or conception of justice differs sharply from John Rawls' theory of justice. In A Theory of Justice, Rawls (1972) states that each person has an equal claim to basic rights and liberties, and that inequality should only be permitted to the degree that such inequality is "reasonably expected to be to everyone's advantage" (234). There is a further provision that such inequalities are only permissible insofar as there is an equality of opportunity to benefit from these inequalities. Nozick (1974) rather argues that people who have or produce certain things have rights over them: "On an entitlement view, (production and distribution) are not separate questions... things come into the world already attached to people having entitlements over them" (p.160). Nozick (1974) believes that unjustly taking someone's holdings violates their rights. "Holdings to which people are entitled may not be seized, even to provide equality of opportunity for others" (235). Thus a system which works to reduce the rightly earned holdings of some so that they can be equally distributed to others is immoral. Nozick (1974) writes:

The major objection to speaking of everyone's having a right to various things such as equality of opportunity, life, and so on, and enforcing this right, is that these 'rights' require a substructure of things and materials and actions; and other people may have rights and entitlements over these. No one has a right to something whose realization requires certain uses of things and activities that other people have rights and entitlements over (238).

Nozick considers redistribution of wealth to be unjust because it calls for heavy regulation or re-distributive taxation which are practices that violate our liberty to our just possessions. To understand Nozick's sentiments in this regard, let us consider our current practice of taxing people more when they earn more. Peggy the materialist likes to spend her extra time working a little more than she would need to in order to feed, clothe and house herself. She works extra hours so that she can buy some extra luxury goods and services. On the other hand, Sue the naturalist likes to work the bare minimum number of hours that she needs to in order to support herself. She spends her extra time hiking, swimming etc.

Peggy has more material wealth than other people but her acquisition has not made anyone else better off. Should we take some of these goods away from her to restore the just Ralwsian pattern? It appears this is what we already do via taxation. Peggy gets taxed more than Sue who may not get taxed at all assuming she earns too little to be considered taxable. But let us imagine that Sue reaps the benefits of the taxation of others by driving on roads built with money, attending public schools and benefiting from the protection by police and military. Is it fair then, that, just because Peggy enjoys the sorts of things that cost money and therefore has to work longer hours in other to afford them, she is taxed a lot more than Sue who thinks the best things in life are free?

To Nozick, it is bizarre that we currently focus on monetary or material wealth, but not experiential wealth. Sue has a lot of great experiences and is in fact better off than most people in some respect. Perhaps Sue should be taxed but in a different way like by similarly taking 8 hours of her leisure time each week such as the government takes 8 hours' worth of pay from Peggy each week. But most people will argue that forcing Sue to work for the government for 8 hours each week is clearly unjust and is in fact slavery. In any case, is the taxation that Peggy endures any different from this? Nozick (1974) says, "seizing the results of someone's labour is equivalent to seizing hours from him and directing him to carry on various activities" (243).

Nozick believes that we should be free to do what we want with our goods because we earned them and therefore forcing us to hand over a portion of our time, goods or money is slavery, theft and in fact unjust. It is wrong to forcefully take anything that we have away from us. Nozick concludes that taxation, of the redistributive sort in which modern States engage in order to fund the various programs of the bureaucratic welfare state, is morally illegitimate. (Edward Feser, 2014). Such taxation amounts to partial slavery, for in giving every citizen an entitlement to certain benefits (welfare, social security, or whatever) the State in effect gives them an entitlement, a right, to a part of the proceeds of your labour, which produces the taxes that fund the benefits; every citizen, that is, becomes in such a system a partial property right in part of you i.e. in your labour. But this is, according to Edward Feser (2014), flatly inconsistent with the principle of self-ownership.

\section{The Minimal State}

In Nozick's opinion, the minimal State arises to advance the claims of individualism and self-ownership of properties and the provisions of the entitlement theory. It is one, which, through a monopoly of force, enforces Nozickean rights and maintains the inviolability of the individual but nothing more. According to Galvin Chia (2010) whilst conventional conceptions of the State usually imply functions such as the provision of public goods, arbitration and taxation, Nozick sees this as incompatible with our fundamental rights. The funding of such State functions more often than not requires taxation which is a State violation of a citizen's right to property. For Nozick (1974), public services, such as the provision of defense and healthcare, are seen as unjust 
redistributive efforts which violate property rights (238). This is against the essence of the State for in Nozick's hypothesized State of nature people freely submit to some protective agencies that would offer them some protection against violence, be it against their persons or property. The protective agency arbitrates between individuals as well as interest groups and mete out punishment to any erring individual as well as any interest group (Irele 93). The protective agency would satisfy the minimal conditions for being a state, yet would have arisen without violating anyone's rights or freedom. Nozick therefore sees such a minimal State as the most extensive State that can be justified. Here Nozick differs from those anarchists who argue against the existence of the State in any way whatsoever.

Nozick argues that any State more powerful or extensive than the minimal night-watchman State that protects its citizens from force and fraud and like things impinges on the individuals' natural rights to his or her holdings and therefore is not legitimate or justifiable (Moore \& Bruder, 2002).

\section{African Communitarian Idea of Justice}

According to Gyekye (1987) Communalism or Communitarianism (Gykye uses the two terms to mean the same thing) may be defined as the doctrine that the group (that is, the society) constitutes the focus of the activities of the individual members of the society. He further states that the doctrine places emphasis on the activity and success of the wider society rather than, though not necessarily at the expense of, or to the detriment of the individual (155). Communitarianism as a philosophy is founded on the values of social well-being, solidarity, interdependence, cooperation, care, concern and reciprocal obligations. These values are sure foundation for human well-being since no single individual is self-sufficient to meet the essentialities of his personality. Human life is characterized by adventures, ambitions, dreams, desires and aspirations. This is a truism. But of no less truth is that human life is equally characterized by weaknesses, frustrations, hindrances, limitations and failures. However, these limitation and frustrations can be overcome when and if a person receives the necessary motivations, care and helps. Human beings need help: help of fellow humans and the help of his/her community to help him/her overcome challenges of life and set him/her on the right path of progress.

Communitarian idea of justice expresses justice as the most basic and all embracing moral disposition of man within the communal society. By this, we mean, justice as a disposition which rules human relations between man and man; man and things in nature and between man and the absolute. In these relations (especially that of man with man), the question of the absolute enters the narrative in the context that we should see other human beings as God's images like we are who are entitled to decent living as we do and so should be treated with care, love and compassion, helping one another (as our brothers' keepers) to lead a decent life of well-being. The acceptable disposition favours and encourages the virtues of coexistence, co-acceptance, care and sharing that make possible the philosophy of being-with and living-for others which is a foundation for the blossoming and the flowering of human life and society. This idea of justice is largely based on the principle of I- am because we-are and since we-are, therefore I-am.

This is how Tempels (1959) presents the disposition of coexistence and belongingness that characterize the African (Bantu) communal society.

Just as Bantu (Black Africans) ontology is opposed to the European concept of individuated things existing in themselves, isolated from others, so Bantu psychology cannot conceive of man as an individual, as a force existing by itself and apart from its ontological relationship with other living beings and from its connection with animate or inanimate forces around it (103).

Chukwuemeka Ekei (2001) captures the idea of African communitarian justice as an interplay of the community and the individuals' (176). Presenting this interplay as a triangle, he writes, "At the base-edge of the triangle is located the community with its various degrees of obligations (duties, the ought and the ought not) meant for the individuals at the other edge of the triangle, to accept, to care and to have concern for" (176). The thoughts of Ekei captures the sense of duties and obligations that characterize the communal society. However, it's worth explaining here that these duties and obligations are not dependent on or restricted to the idea of justice as 'giving to everyone what is his due' for there are people who for some reasons have nothing due to them, but who need to be taken care of by virtue of their membership of the communal society. Thus, the provision of communal obligations by the community is for the survival, the flourishing and the welfare of its members. According to Ekei, the "acceptance" and the "caring" of the same by the individuals create a moral relationship between the community and individuals and among the individuals themselves (176).

Giving people their due is laudable but only possible if those who are to do the giving (the privileged) "accept" this moral option (the obligation) to do so. Again, for those who may not have anything due to them by no fault of theirs and indeed no fault of anyone, to live a minimally good life, there is need, on the part of the privileged, to "accept" the humanity of these less privileged (the worse off of the society) and on the basis of their humanity, share with them their inherited or transferred resources and talented productivities. But this can only be done on the basis of caring or compassion or generosity. Kwame Gyekye (1997) echoes this when he 
avers that in the communitarian moral universe, caring or compassion or generosity, not justice (which is related essentially to a strictly rights-based morality) may be a fundamental moral category because in a moral framework where love, compassion, caring, friendship and genuine concern for others characterize social relationships, justice (which is about relations of claims and counter claims) may not be the primary moral virtue. By justice here, Gyekye is referring to Western theories of justice.

The issue of "what is due or not due to someone", that is, claims and counter claims of "rights" - "I have the right" or "you have no right to..." do often evoke latent war and awaken the spirit of contention which can better be resolved by charity, generosity or compassion and not necessarily by litigation. Simone Weil (1998) had echoed this long before now when she says that, "To place the notion of rights at the center of social conflicts is to inhibit any possible impulse of charity on both sides".

The continued coexistence of the black people of South Africa (the natives) and the whites who formally oppressed them during the dark days of Apartheid is made possible not on the right-based justice but on compassion-based justice. On the basis of rights or that which is due to someone, what is due to the Whites is to possibly send them parking from South Africa or to make life unbearable for them, but justice as compassion, love and generosity says, "allow them coexist with us on the basis of their humanity". This is made possible through the Truth and Reconciliation Commission (TRC) framework.

This kind of disposition and setting promotes the virtues of coexistence, acceptance, care and concern that make possible the flowering of the human society where the interest of all is protected and the well-being of all guaranteed.

In recognition and support of this thesis, Frederich Nietzsche, in spite of the radical individualism that may be found in his philosophy, recognizes that a "sovereign individual" (the privilege) in "transcending' another individual cannot oppress the other; and recognizes in her freedom a moral responsibility to others. These thoughts are echoed in Nietzsche's 'man of the future'. Richard Bell (2002) writes that:

In a Nietzschean society, given that a two-tiered class society is recognized, a "noble" class and the "herd" - those who have the noble sentiment must not use their strengths to "lord over" or "oppress" others either within or between classes. In fact, a good "lord" is generous (emphasis mine) as part of his responsibility. Mutual respect forms the basis for society and one's continued identity depends on the larger community functioning to sustain (and allow) everyone's freedom and well-being (64).

\section{Some Critical Remarks}

Nozick's political thought sparks an extreme form of unbridled individualism. In a situation where people are free to do whatever they like with their goods and properties without necessarily considering the plights of the have-nots may certainly not help us in our quest for a good human community. It is not enough that people are not made worse off by our positions or possessions, it is important that we make people better off with our position and possession. As communitarian persons, we should be interested in the welfare of other people of our community. Life is unmerited and most of our talents, abilities and possessions are unmerited too. In fact, to sound biblical and indeed commonsensical, "to whom much is given, much is required". So we should use our advantaged positions (on the basis of love, care and compassion) not only not to make others worse off but also, to make others better off. Unremitting pursuit of personal profit (which is a fundamental feature of extreme individualism) is even more corrupting than submission to arbitrary power (Monro, 1986). I have argued elsewhere in a paper entitled, Between Individualism and Communitarianism in the Quest for a Good Human Community, that "Individualism as a social arrangement is steeped in egoism, unhealthy and divisive competition, extreme quest for personal rights, disdain for public interest and common good and for this very reason constitutes a bane for social order, whereas communitarianism, of the African type, with its values of solidarity, altruism, synergy, interdependence and cooperative togetherness, is foundational for social cohesion requisite for a full realization of personhood and a good human community" (Obioha 3-17).

Nozick appears to celebrate individual freedom above social cohesion though he erroneously believes that unrestricted human freedom will help establish justice. Nozick therefore advocates the greatest possible minimization of the activities and powers of the state and its replacement with a minimal State devoid of all instruments of restraint and coercion. But, much as freedom is necessary to man, being also an indispensable precondition of ethics, it is difficult to apprehend the nature of the society where absence of all restraint is absolutely encouraged. Without a certain degree of social control, human passion will uproot the ethical foundation of the human society. If the coercive instrument of the State is abolished as unnecessary, social cohesion is likely to be disrupted by the obvious human ambivalence. Man, being what he is, to implement Nozick's idea of unbridled individualism is therefore to invite another "Hobbesian state of nature".

Nozick's entitlement theory lacks the human feelings of sympathy, co-existence, acceptance, care and concern which we have espoused above. Every society naturally has, as members of that society, the worse off the weak, the poor and the needy who depend on the sympathy, care and concern and generosity of others to 
barely sustain their lives. In Igbo communal societies, these worse off members of the community (the poor, the needy) are called Ogbe-enye. Ogbe means the community while the verb enye means to give. Simply ogbe-enye means community gives. These set of people, by virtue of their humanity, are members of the community and thus depend on the community to give them the means to lead at least a minimally decent life on the basis of care, acceptance, concern and generosity. The pursuit of a good human community requires that these members of the society be taken care of. This may require taxation or redistribution of resources (on the part of the well-off but not because the worse-off have such 'rights' to claim from the well-off, but only on the basis of sympathy and care) so as to make them well-off. But any theory of justice that discourages this, as the entitlement theory does, cannot be said to be fair to the already worse-off. Therefore, justice as co-existence, justice as acceptance, justice as care, justice as sympathy and justice as concern is needed in our pursuit of a good human community for the realization of full personhood and the flowering of human personality and potentiality.

Nozick's penchant for extreme individualism can be counter- productive. For instance, leaving everything to the market forces might result in an unjust social arrangement in that those that are weak or the poor might not be catered for and consequently their freedom which Nozick claims is of special importance might not be realizable (Cohen, 1979). Nozick's philosophy does not have any serious consideration for the welfare of the people. Goldman (1976) asserts that Nozick's principles place 'absolute priority of the freedom of the individuals over their welfare', and from a commonsensical approach this is problematic. What is freedom without welfare? Any freedom that leaves me incapable and incapacitated to have the basic necessities to lead at least a minimally good life is not an adequate or robust understanding of freedom - an "integral freedom" to use the words of Pantalean Iroegbu (2002) or "positive freedoms or capabilities" (Armataya Sen, 1999). Freedom-from is good but much more important is freedom-to and freedom-with which enables me to lead a minimally good life (Obioha, 2015).

Nozick's lexical priority of freedom before welfare suggests, ironically, that we are bound to his concepts of freedom. From the Tale of the Slave, this implies that it is morally justified if we are free and impoverished, but morally wrong to be in slavery and tremendously well off. A system of morals which fails to take into account the welfare of its moral agents is clearly flawed - how are we to exercise the freedoms that we are entitled to if we are physically in no condition to do so? What good are your property rights, or for that matter, anybody else's, if you are too hungry to move? The minimal State, being the un-intrusive entity that it is, has no answer to this.

Galvin (2010) raises some serious questions concerning justice in initial acquisition. In a historical context, there have been many instances in which the appropriation of property has been carried out through force, coercion or in otherwise unjust fashion. For instance, the violent appropriation of land in North America and Australia by early European settlers is a clear case in which initial acquisition was unjust and has remained unrectified to this day.

Nozick's model calls for the rectification of these past transgressions of indigenous property rights. Though this is currently achieved in some cases through fiscal compensation or affirmative action schemes, under Nozick's system of rights this would be illegitimate. Its illegitimacy is not simply because they would be services provided for by an illegitimate, more-than-minimal State, but also because they would require funding through taxation, which is in itself a violation of the property rights of the taxed (Kymlicka, 2002). Galvin argues that the only available option would be to return all the land unjustly claimed from indigenous peoples which will include much of North America, and virtually all of Australia. But what will be the fate of the Australian property owner who has justly bought what was initially unjustly appropriated land? Will not his right to property be violated as well? Galvin points out that these two tensions remain unresolved by Nozick.

In the light of this, Cohen notes that as long as historical injustice is unresolved, Nozick's entire position on rights and the minimal State is rendered nigh invalid. Granted, historical injustice violates property rights. If property rights are allowed to remain compromised, then there is no moral objection to further infringing property rights through taxation (Cohen, 1979). This means that the minimal State would cease to be the 'most extensive State that can be justified.

\section{Conclusion}

In this paper effort has been made to understand Nozick's political philosophy. This is done through an analysis of the three key terms which feature prominently in his political thought namely: individualism (self-ownership), justice and the minimal State. It has however been pointed out in this paper that Nozick's entitlement theory which expresses his concept of justice leaves much to be desired in that it lacks the human feelings of coexistence, acceptance, sympathy, welfare, care and concern for others. Any meaningful quest for a good human community must recognize and practice these principles of justice, that is, justice as co-existence, justice as acceptance, justice as sympathy, justice as care and justice as concern for others.

\section{Works Cited}

Bell, R. (2002). Understading African Philosophy. New York: Routledge. 
Cohen, G. (1995). Self-ownership, Freedom and Equality. Cambridge: Cambridge University Press.

Cohen, G. (1979). "Capitalism, Freedom and the Proletariat". In The Idea of Freedom: Essays in Honour of Isaah Berlin (ed.) A. Ryan. Oxford: OUP.

Dipo I. (1998). Introduction to Political Philosophy. Ibadan: Ibadan University Press.

Edward F. On Robert Nozick. http://www.iep.utm.edu/nozick/ Accessed 20 June, 2014.

Ekei, C. (2001). Justice in Communalism. Lagos: Real Communications Ltd.

Galvin C. (2010). "No Man an Island: Refuting Robert Nozick's Libertarian Political Philosophy". Cross Sections. Vol. VI. 2010. 137-146

Goldman, A. (1976) "The Entitlement Theory of Distributive Justice". Journal of Philosophy. 73(21).

Gyekye, K. (1997). Tradition and Modernity: Philosophical Reflections on the African Experience. Oxford: Oxford University Press.

Iroegbu, P. (2002). Treatise on the Human Person. Owerri: EUSTEL Publication Inc.

Kymlicka, W. (2002). Contemporary Political Philosophy. 2nd edition. Oxford: Oxford University Press.

Monro, D. (1986). "Modern Political Ideas: A Dialogue". In Political Thinkers (ed.) David Muschamp. London: Macmillan.

Moore, N. \& Bruder, K. (2002). Philosophy: The Power of Ideas. Fifth ed. USA: McGraw-Hill Higher Education.

Murray ,D. (2014). Robert Nozick: Political Philosophy. Internet Encyclopedia of Philosophy. http://www.iep.utm.edu/nozick/ Accessed June 20,2014.

Nozick,R. (1995). Anarchy, State and Utopia. New York: Basic Books.

Obioha, P. (2015). A Thomistic and African Communal Idea of the Human Person. Germany: Lambert Academic Publishing.

Obioha, P. (2016) "Between Individualism and Communitarianism in the Quest for a Good Human Community". Journal on African Philosophy. Vol.13, 2016. Africa Resource Center, USA.

Sen, A. (1999). Development as Freedom. New York: Alfred A. Knopf Inc.

Rawls, J. (1972). A Theory of Justice. Oxford: Oxford University Press.

Tempels, P. (1959). Bantu Philosophy. Paris: Presse Africaine.

Weil, S. (1998). The Way of Justice as Compassion. Lanham, MD.: Rowman and Littlefield Publishers. 